\title{
Care of the self in a social group for elderly women
}

\section{Abstract}

Objective: to discover the meaning that a group of elderly women attributed to the dialogical sharing of experiences with their peers, and the way this was inserted in the process of living and aging, relating the findings with Care of the Self by Michel Foucault. Method: an exploratory, descriptive, qualitative study was carried out with 28 elderly women enrolled in the "Dialoguing Emotions" Workshop, a social group linked to a university in the countryside of the south of Brazil, through an interview and discussion based on the themes of their experiences. That which emerged from the interviews and discussions underwent content analysis. Results: the extraction of units of significance allowed the elaboration of two intertwining thematic categories: Experiences and strengths of aging in a group: the voice of the elderly and the care of the self: looking at myself and the other. Conclusion: an appreciation of the group relationships was identified, and this experience generated empowerment among participants when dealing with life challenges, providing new possibilities for overcoming subjective limiting experiences. The interaction with a space of listening and free expression, contributed to the rediscovery of oneself, enabled new ways to make oneself a subject in a late stage of personal existence, which in practical terms, has repercussions on emotional balance and greater awareness of the self, providing relief, motivation and determination to meet the challenges of longevity.
Helenice De Moura Scortegagna' $\mathbb{D}$ Nadir Antonio Pichler' (DD Jarbas Dametto ${ }^{1}$ Silvana Gazzana' 1 D Eliane Lucia Colussi' (D)

Keywords: Aging; Subjectivity; Groups of Coexistence; Care of the Self; Foucault.

\footnotetext{
Universidade de Passo Fundo, Programa de Pós-graduação em Envelhecimento Humano. Passo Fundo, Rio Grande do Sul, Brasil.
}

Correspondence

Nadir Antonio Pichler

nadirp@upf.br 


\section{INTRODUCTION}

Phenomena associated with increased longevity and the changing roles of women in the labor market, as well as the emergence of new family configurations, are impacting and changing the lifestyle of elderly women. The elderly are faced with a vast range of possibilities for becoming the subject, which sometimes conflicts with the limiting discourses that exist even day. If in other eras women had to adapt to social, cultural, sexual and moral norms, traditionally anchored in the patriarchal paradigm, there are now alternatives for a re-dimensioning of subjective, family, social and financial experiences. Faced with this transition, one of the spaces found for channeling, expressing and finding new ways of being and acting are social groups ${ }^{1}$.

Social groups, created by governmental and nongovernmental bodies, are understood to be spaces of communication and are recognized as a form of social and emotional support for the elderly. They are important strategies for improving the health and quality of life of this section of the population, by allowing the affirmation of identity and encouraging participation, which is expressed by the social protagonism of the elderly individuals. They can improve quality of life through the art of well-being and care of the self².

The Care of the Self, thematized in the works Hermeneutics of the Subject and The History of Sexuality 3, by the French philosopher Michel Foucault (19261984), developed around the theme of subjectivity, distancing itself from experience derived from historically instituted relations of knowledge and power, and the target of many of his previous studies. To achieve this, the author immerses himself in the Greek and Roman Hellenistic tradition, emphasizing the epicurean, stoic and cynical philosophies of the first two centuries of the Christian era, calling it the "golden era of the Care of the Self", undertaking a genealogy of the subject based on practices aimed at the self. Of this historical-philosophical context, says Foucault, "all the knowledge we need should be ordered by tékhne toû biou (the art of living), a theme as much stoic as it is epicurean or cynical"'. As such, the role of this philosophy is to stimulate the individual to practice the art of living well ${ }^{4}$.
For Foucault ${ }^{5}$, the care of the self, from the Greek epimeleia heautou, means caring for the soul, the self. It consists in seeking a philosophy of life that exalts "the conditions and the undefined possibilities of the transformation of the subject", capable of discovering a new self and impelling it in search of itself, molding it, as it is intrinsic and coextensive to the life of person to know and take care of oneself ${ }^{6}$.

In this sense, in order to understand the subjective experiences of the participation of elderly women in a social group, the researcher participated in meetings of this group and, together with the elderly women, sought to identify feelings and alternatives of life emerging from the established group relationships. Therefore, the objective of the present study was to identify the meaning that a group of elderly women attributed to shared dialogue of experiences and encounters with their peers. The results were discussed in the light of the problematizations of Foucault's care of the self.

\section{METHOD}

A qualitative study of exploratory and descriptive type was carried out with a social group linked to the extension program of a university in the interior of the south of Brazil. The study population consisted of 28 elderly women enrolled in the "Dialoguing Emotions" workshop. This represented the total number of elderly women enrolled in the workshop, with no exclusions or losses. Individual interviews were used for information collection. These were carried out in 2015 and followed the criterion of the gradual inclusion of participants, known as gradual theoretical sampling. Data collection was finalized when the theoretical saturation of the subject being investigated occurred. Therefore, the interviews included eight randomly selected elderly women and occurred at a date, place and time previously agreed with the participants. The instrument used was the topical guide that addressed the theme: conversations between the women and their meanings in the experience of living and aging. For the validation of the data collected in the interview, the rest of the group, consisting of 20 elderly women, was divided into two groups of ten, each of which participated in a thematic workshop of approximately $1 \mathrm{~h} 30 \mathrm{~min}$. The workshops took advantage of play resources and self-expression. 
The original meetings of the workshop offered by the Dialoguing Emotions group were weekly and lasted two hours, with times for exchanges and discussions about feelings, memories, experiences, health, the body, the mind, relationships with parents, partners and children, friendships, sexuality, work, crises of maturity and finally, with questions related to living and aging, with the aid of texts of various types, such as poetry and short stories, among others, as well as movies, music and images.

The information obtained in the interview and in the validation workshops were qualitatively analyzed using Bardin's thematic content analysis ${ }^{7}$, in which the elements were classified by common characteristics and their subsequent categorization, comparing the data collected through the perspective of Foucault's Care of the Self. The study was approved by the Ethics Committee under approval No. 441.408, according to Resolution N. 466/12, by means of the signing of a Free and Informed Consent Form. Participants are identified as E (elderly), and the Arabic numerals corresponding to the order of the interview.

\section{RESULTS AND DISCUSSION}

That which emerged from the words of the elderly unfolded into categories that intertwine and complement each other. Two categories were therefore established: a) experiences and strengths of aging in a group: the voice of the elderly women and b) care of the self: looking at the self and the other.

The category experiences and strengths of aging in a group: the voice of the elderly women revealed that the group allowed the sharing of subjective experiences, with a common personal and family identity emerging from talking about oneself, which generated a sense of solidarity and an altruistic experience, and one of participation and social protagonism in relation to the feelings experienced. The following statements illustrate this perception:

"I found out that I'm not the only one who has problems [...]. That all families are the same [...], they have single mothers, alcoholics, are separated, there's one who goes to school ..., one who earns a lot, one who doesn't work, that everyone goes through the same pain. When I shared this, I discovered that there were a lot of mothers who had gone through the same thing, who had suffered too, who had done well [...]. So for me it's an example that it's like this for everyone" (E3).

"It's because we get there and see that everyone has problems, not just us" (E1).

The participants characterized the group as one of "solidarity", as a space of social insertion to express the existential problems of daily life and the feeling that the process of living and aging is accompanied by challenges such as the need to solidify and renew their personal life, their social and cultural projects, their conduct, temperament and behavior. These reciprocal exchanges contributed to the intertwining of ideas and thoughts, listening, respect and dignity, with new learning and the synthesizing new meanings for caring for the self.

"One day they listen to me, the next day I'll listen” (E1).

"'The greatest meaning of this group, is that it has taught me to listen and respect the thinking of others, because [...] each person has their way of growing. So it's an extremely cohesive group, very good to get along with, I've grown a lot" (E7).

"Look! I admire the variety of people, the feelings of people, the lives of people, that people are very different from ourselves. So, for me, this is very interesting. I think I have patience, I like to listen" (E5).

These reports indicate that women have structured a space of renewal in the field of aging. This scenario is conducive to the formation of a social, ethical identity capable of meeting the biopsychosocial and cultural needs of women going through old age.

Corroborating with the experiences, meanings and social interactions expressed by the elderly in relation to the sharing of experiences, Foucault's idea

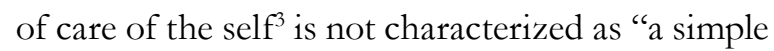
momentary preparation for life; it's a way of life." It has a therapeutic, curative and creative dimension, where the individual immerses themselves in their subjectivity, their soul, becoming the owner 
of themselves, being able to generate autonomy, independence, empowerment, self-government ${ }^{4,5,6}$. It is a lifestyle that seeks, in a continuous and progressive manner, to exercise, experiment, and generate confidence. It is "to turn our gaze upon the things of the world to lead it to ourselves" . Care of the self consists of a kind of "ethical conversion of the subject defined by the relation of the self to the self"

For the Greek and Roman philosophers, including Socrates, Plato, Aristotle, Diogenes of Sinope, Epicurus, Seneca, Epictetus, Marcus Aurelius, it is never too late or too early to know and take care of oneself ${ }^{3,5,6}$. It is a continuous exercise, focused on self-knowledge, self-mastery, tranquility, how to meditate when getting up or lying down, creating daily activities and examining them as a practice of daily life. According to the following statement, the participant seeks to reflect on their existence on a daily basis and this care of themselves motivates them to face daily activities:

\footnotetext{
"I am someone who loves to reflect. [...]. When morning comes, I thank God for the day, because I am waking up, that he gives me strength, perseverance, so that I can overcome all the obstacles that appear in the best way possible, and when I get to the night [as well]" (E7).
}

Specifically, "Foucault found that, in the imperative of 'occupying oneself', a possibility of elaborating oneself as an end in itself, that is, in the Hellenistic tradition, he found a self-finalization of care of the self"'. This self-constitution seeks to develop an active ethical subject, defined as the practice of the self. It is a technique that enables the subject, alone or with the coexistence of another, to carry out actions involving their body, soul, feelings, thoughts, attitudes, with the purpose of achieving happiness, purity of the emancipated and sovereign soul, tranquility when faced by existential finitude ${ }^{10}$. The discourse below signals this perspective, which is not an easy task:

"In the beginning it took a while, because we [...] thought that we didn't need to talk about ourselves. [...]. In the workshop I managed to get it out because sometimes a person gets sick because they don't talk. [...]. When I see a sick friend, I say, "Hey! You need to go to [Workshop], talk, get it out “ (E6).

"It was a time when I was sick, nervous, sad. I had lost my brother [...]. [The Workshop] helped me. We can talk about our problems, our feelings. [...]. I was a very closed off person, extremely unhappy, I had no pleasure at all" (E2).

Listening to the other is an attitude of consideration and respect, a means of communication, of sedimentation of experiences ${ }^{10}$. According to the statements described, the workshop generated a social identity of subject, participatory character and citizenship, of social protagonism. The other, in Foucault's view ${ }^{3,4,5,6}$ cannot be ignored in the constitution of self-care, because he or she characterizes the subject as belonging to humanity, that is, the bearer of existential meaning with which actions and reactions of a predominantly political and ethical nature are established. As Wanderbroocke et al. ${ }^{2}$ states in a literature review study, feelings of the social identity of the elderly can be elicited by sharing in social groups, experienced as attitudes of motivation and participation, trust, justice, interaction, well-being, quality and satisfaction with life, reducing experiences of solitude and isolation.

In the category The care of the self: looking at the self and the other specific characteristics of the aging process emerged, namely appearance, social roles, group of friends and family life. These changes, which for a long time were seen only as losses, now provided subjective realizations, as the participants felt free of their traditional commitments, becoming protagonists of changes in the representation of old age, being able to reflect on their choices and their desires, as can be seen in the excerpts of the following discourse.

"I sought out [the group] with the intention of finding resources to improve my emotional side, to live with the situations, especially the conflicts, which always followed me and I think they always follow people, some more so, some less so" (E4).

"I really like the texts, because if I was to read at home on my own, I wouldn't go into them as much, like we do here" (E6). 
"I was so shocked with my age, I did not see that I had aged. I was kind of desperate at the time. Then I started to come to this group, to make myself aware that everyone has a problem. [...]. One way or another, then you have to deal with it. The bond I have with them [...] is an affection that we create, an affective bond! It is so affective, let's say broad, because you have confidence in the people, in the group!" (E2).

In these reports, it is inferred that participation in the workshop contributed to (re) finding oneself. The unreflective everyday experience kept the elderly women busy with the attributions of family and professional life, making care of the self something that was ignored or forgotten.

In the perspective of the care of the self proposed by Foucault ${ }^{3,5}$, if a person's life is not examined, reflected upon and continually self-assessed, the subject runs the risk of being abruptly taken aback by some unexpected event and seeing their life disintegrate in the dimension of roles and senses. The lack of reflection and self-care leads to the loss of subjective conditions of emotional support for coping with life's setbacks.

In the freedom of speech (parrehsia), proposed and sustained by support groups, the subject emerges in its potential for self-construction and the assumption of desires, breaking with the contingencies that linked the individuals to historically constituted static roles that weaken in the perspective of life of the senile individual:

You have confidence, you can talk, sometimes you say things that you always thought you would never talk about, because it is something that embarrasses you, there are things in life that you do not want to talk about [...], [because] they become public domain" (E4).

“Sometimes at home we don't say anything, we don't talk because it hurts the ones at home, they get sick of us complaining every day. And here we have the freedom to talk, to express our problems, our feelings, that is why I am still coming today" (E6).

"My dream is to have a boyfriend" (E7).
In these reports, the idea of returning to oneself occurred. It is inferred from this, that the space provided by the group for talking about particularities, gave the subject the strength to look at the world and the events of life with more bravery, with new expectations, new affective approaches. This way of caring for oneself, makes the subject, the elderly person, into a supply of subjective resources, of the soul, such as courage, moderation, tranquility, self-control (enkrateia) and their desires, shaping their conduct to tackle personal challenges and live better ${ }^{11,4,5}$.

Through coexistence with others, with someone and something that is different, the elderly women have been able to see themselves, their attitudes, the social roles played out in the course of their lives, which were then shaped by social, cultural, religious, moral, orders, according to the traditional references of family and old age, for which women only perform the function of mother, grandmother, servant of the home, of the husband, often submissive, even in their sexual life. The care of the self encourages the subject to establish new relationships "with the woman, with others, with events and with civic and political activities" . Now, the care of the self analyzed by Foucault proposes that the subject awakens from itself, with autonomy, responsibility, tranquility.

It is the art of living well, which means shaping one's own life, through immersion into subjectivity, into the values of the soul, establishing a style of freedom. "The subject of care of the self has as their first condition being shaped by one's own practices" ${ }^{\prime 2}$. It is to assume and recognize oneself as a subject, as a participant of a world of possibilities with oneself and with others, as a being in the world. The aesthetics of existence is a choice of existence. The statements below summarize this insertion in a group and the immersion in the self:

"Participating in the group was the biggest investment I ever made [...]. It was very good. It was as if I had put together the pieces that were half disjointed and had formed a new being, or a whole being. So being here gave me another vision, I see it as a therapy" (E8).

"I'm a little reserved, I like to listen more, so the experience of one, of the other, works for me too" (E6). 
"Here we can talk, get things out and people listen. Sometimes I do not think I'm going to reveal this in front of the group [...] but then we ended up creating this bond, that makes us talk, this trust that was created between us" (E4).

"I've been coming to Dialoguing for more than three years. We learn because we have people who have also been through the same thing, they give you encouragement [...] sometimes we think it's just us who are going through it, but it's not" (E8).

"I think it's important to have these groups, not just here for us, [...] but if everyone could participate it would be nice" (E3).

Caring for the self focuses on occupying the self. This restless position of seeking oneself has become a principle of rational, moral conduct in the world of Hellenistic and Roman thought and "a true cultural phenomenon as a whole"' 3 . In this moral itinerary, the subject becomes master of themselves, not in the perspective of a "universal law, to which each and all should submit; but above all as a principle of stylization of conduct for those who want to give their existence the most beautiful and most accomplished form possible"3.

The well-being, the self-care provided by the coexistence of the elderly women in a group, demonstrated that exploring the depths of the soul, sharing emotions, becomes a fuel, capable of driving new projects, giving meaning to existence. This way of caring for oneself acts in thought, feeling, the perception of oneself, in others and in the world, generating an action, a transformation in the manner of being of the subject, forming a "new being", as expressed in the words below.

"I discovered that I am not the only one, that everyone is the same and goes through the same pains. We change our ideas and see that we have how we got through it [...], that we are the winners!” (E5).

"I want to move on, I do not want to go back [...]. The family noticed this, a change" (E3).
"As a human being, each has of us has our growth, [...] our understanding. [...]. I think that we have to realize what is good for us, not when its imposed on us, because when it's imposed, it's very difficult" (E7).

Corroborating this, one can evaluate that "the existence of collective spaces for the exchange of experiences, as well as the informal contacts of daily life, contribute to bringing the interlocutors closer"'. Therefore, caring for the self is an attitude, a way of being and acting in the world and with others ${ }^{4,5,13,14}$. This attitude toward the self makes the subject "consider themselves as an object of knowledge and field of action to transform themselves, to correct themselves, to purify themselves, to obtain their own salvation, etc" $"$.

In order to reach this level of moral development, that is, this practice of the self, the care of the self can be related to parrhesia, which means speaking the truth, with frankness, being true to oneself, openness of thought, accepting oneself, the "courage of the truth ". [...]. Parrhesia involved a series of essential elements to consider the relations between philosophy, ethics, truth, politics and democracy in antiquity". Yet, parrhesia is a "way of saying, [...] an ethics of the word [...]. It is the opening of the heart, it is the need, among our peers, to hide nothing from each other and to think and speak frankly"3.

\footnotetext{
"We see that others sometimes have problems that are much more serious than what we are going through. But there came a time when none of this gave me what I needed. It was full of conflict. [...] They were two, three things inside - feelings, emotions that fought within me" (E4).
}

One of the ways of practicing parrhesia is to establish and maintain friendly relationships, especially in old age, because they help and provide emotional and motivational support, including feelings of belonging, trust and encouragement ${ }^{13,14,15,16}$. "Friendship was generally centralized around an individual with whom some were closer and [others] less close,"3 as well as being the only condition in which one can bear the risks of the frank enunciation of the truth. 


\section{CONCLUSION}

For the women in this study, sharing experiences in a social group, both through speech and listening, had a positive meaning. The reports of the participants demonstrated that in this space identifications and formations of significant bonds occurred, new demands and perspectives appeared in a late stage of life. Therefore, this space of sociability for the elderly contributes to emotional balance, allowing them to face the challenges of longevity and giving them greater capacity to be inserted in other required contexts of life.

According to the discourse of the participants, the expressions that emerged exalt the search for self-care, such as: learning, helping, welcoming, joy, alliance, friendship, love, collaboration, sharing, trust, communication, knowledge, comprehension, coexisting, complicity, dialogue, pain, understanding, bonding, family, happiness, history, imagination, different ideas, memories, dividing things, remembrances, respect, revival, solidarity and equality. Now, the philosophy of care of the self requires vigilance, energy, learning to live and to

\section{REFERENCES}

1. Moura MMD, Veras RP. Acompanhamento do envelhecimento humano em centro de convivência. Physis. 2017;27(1):19-39.

2. Wanderbroocke AC, Wiedemann AMV, Bussolin C. Participação social e familiar de idosas vinculadas a um grupo de convivência de uma comunidade de baixa renda em Curitiba-PR. Salud soc. 2015;6(3):212-22.

3. Foucault M. A hermenêutica do sujeito. Tradução de Márcio Alves da Fonseca e Salma Tannus Muchail. 4. ed. São Paulo: Martins Fontes; 2010.

4. Lawlor L, Nale J. The Cambridge Foucault lexicon. New York: Cambridge University Press; 2014.

5. Foucault M. História da sexualidade 3: o cuidado de si. Rio de Janeiro: Graal; 2009.

6. White R. Foucault on the care of the self as an ethical project and a spiritual goal. Hum Stud. 2014;37(4):489-504. dialogue. All these expressions demonstrated a fruitful dialogue with the self and the other.

The opportunity to share joys and sorrows, to talk about themselves, their identity and their subjectivity, allowed the participants to develop new possibilities for learning, immersing themselves in a reciprocal pedagogical relationship of teaching and learning, capable of generating changes in style and in the projects of individual life, a kind of gerontological education based on one's own experience. This “ laboratory of awareness" of care of the self that the group has provided for the elderly, has allowed the integral empowerment and overall development of these women, demonstrating that human biopsychosocial development can be a permanent process, extended to all stages of the human existence.

If caring for the self is a lifelong project, the reports of the participants showed that the space for listening, socializing and expressing feelings, achievements, joys, anguish and sadness contributed to the formation of meaningful bonds, of welcoming, dialogue, of finding oneself, of emotional equilibrium, solidarity, providing relief, comfort, motivation and determination to face the challenges of longevity.

7. Bardin L. Análise de Conteúdo. 4. ed. Tradução de Luís Augusto Pinheiro. São Paulo: Edições 70; 2016.

8. Dalbosco CA. Pragmatismo, teoria crítica e educação: ação pedagógica como mediação de significados. Campinas: Autores Associados; 2010.

9. Grabois PF. Práticas éticas de subjetivação e resistência política em Michel Foucault. ECOS Estud Contemp Subj. 2013;3(1):72-87.

10. Xavier LN, Sombra ICN, Gomes AMA, Oliveira GL, de Aguiar CP, Sena RMC. Grupo de convivência de idosos: apoio psicossocial na promoção da saúde. Rev Rene. 2015;16(4):557-66

11. Hadot P. La philosophie comme manière de vivre. Paris: Albin Michel; 2008.

12. Silva NMA, Freitas AS. A ética do cuidado de si no campo pedagógico brasileiro: modos de uso, ressonâncias e desafios. Pro-Posições. 2015;26(1):217-33. 
13. Lynch R. Foucault's critical ethics. New York: Fordham University Press; 2016.

14. Ramirez RH. Technology and self-modification: understanding technologies of s after Foucault. J Sci Technol Arts. 2017;9(3):45-57.
15. Almeida M. As Relações de amizade entre pessoas idosas: significados, funções e intimidade. Atas Invest Qual Saúde. 2016;2:1340-5.

16. Pinho LC. Michel Foucault e o conceito grego de parresia. Poiesis Rev Filos. 2015;12(1):34-43. 